\title{
STUDENTS' ABILITY TO USE DESCRIPTIVE ADJECTIVE IN SENTENCE
}

\author{
HENDRI \\ Dosen Fakultas Keguruan dan Ilmu Pendidikan Universitas Muhammadiyah Palangkaraya
}

\begin{abstract}
This thesis deals with the use descriptive adjective in sentences. The objectives of this research are to find out the students' ability to use descriptive adjective in sentences, and describe the students 'difficulties in using descriptive adjective in sentences.

The technique used in this research was descriptive quantitative. This research took the second year (XI) of MAN Tanjung Morawa. There are three classes for XI students that consist of 102 students in which class XI IPA1 = 30 students, XI IPA2 = 36 students, and XI IPS = 36 students. Since the researcher took $20 \%$, so only 20 students were taken as the sample.

The findings of this research concluded that from 20 students, there were 9 students or $45 \%$ were categorized as able. From 20 students, there were 11 students or $55 \%$ were categorized as unable. The result of validity of the test is 0.67 . It means that the test is "high to validity". The value of standard reliability above, then the result of reliability of the test is 0.80 . It means that the test is "good". The test item number 7 was the most difficult one in which only 2 students were able in using descriptive adjective correctly. The test item number 7 related to the Compound Adjective.
\end{abstract}

Keywords : descriptive adjective, sentence

\section{ABSTRAK}

Penelitian ini mendeskripsikan penggunaan descriptive adjective dalam kalimat.tujuan dari penelitian ini adalah untuk mengetahui kemampuan siswa dalam menggunakan descriptive adjective dalam kalimat dan mendeskripsikan kesulitan yang dihadapi siswa dalam menggunakan descriptive adjective pada kalimat.

Tehnik yang digunakan adalah deskriptif kuantitative. Penelitian ini mengambil kelas XI tahun ajaran Man Tanjung Morawa. Ada tiga kelas yang pada kelas XI yang terdiri dari 102 siswa kelas XI IPA $1=30$ SISWA, XI IPA2 = 36 siswa, dan IPS 36 siswa.

Hasil penelitian menunjukkan bahwa dari 20 orang siswa terdapat 9 siswa atau $45 \%$ dalam kategori able. Dari 20 oraang tresebut 11 siswa atau 55\% masuk dalam kategori unable. Hasil validitas tes menunjukkan 0,67. Artinya test tersebut sangat valid. Hasil tes relibilitasnya menunjukkan 0.80 . atinya tes tersebut dalam kategori baik. Tes nomor 7 merupakan item tes tersulit, hanya 2 orang siswa yang dapat mendeskripsikan dengan baik. Tes nomor 7 berhubungan dengan Compound Adjective.

Kata Kunci : compound adjective, kalimat

\section{THE BACKGROUND OF THE STUDY}

English language, as we have known, has become an international language used all over the world besides some other languages. In Indonesia itself, English is regarded as a foreign language. Students in primary school to university level have to learn this language. English also used in various kinds of communication media.. In one's process of thinking, language plays an important thing, because any kinds of ideas, concepts, views, and desires are manifested through language.

To form an idea about something is the main point of thinking process. The degree of development of culture in any nation is mostly 
seen in the nation language including its vocabulary. Vocabulary or words are essential in communication. Little children learn to speak in isolated words and then chains of noun and verbs as Arnold (1995:24) explains.

We expect students of a second language, however, to control grammatical features of that language as well as its vocabulary. Students who are immersed into a new linguistic setting tend to pick up vocabulary first; will then gradually develop a more accurate structural framework in which to use these words. Rachmadie (1985: 18) said that concrete words are the easiest to learn. Neither younger nor older students have trouble in learning numbers, days of the week, colors, names of objects, and the like. The difficulty arises with using these words in sentences. For this reason, words are generally taught in context.

One of the basic vocabularies is an adjective. Wren and Martin (1993: 19) described that adjective as a word used with a noun to describe or point out, the person, animal, place, or thing which the noun names, or to tell the number or quantity. As to describe a noun, the adjective also has what we call a descriptive adjective. Descriptive adjectives are the largest class of the four types of adjectives, the others being adjectives of quantity, demonstrative adjectives, and pronominal adjectives.

In descriptive adjectives, there are three kinds of it, they are: Simple Adjectives like good, bad, clever, ugly etc, Compound Adjectives like Heaven-derived power, this life-giving book, his spirit wrap, and Proper Adjectives like an old English manuscript, the Christian pearl of charity, the well-curb had a Chinese roof. Besides, understanding the three kinds of descriptive adjectives, students should know how to put the adjective correctly.

Ting (2008: 2) suggested that the order of descriptive adjective can be six common types of descriptive adjectives can be age - size - material - shape - color - nationality and others. Meanwhile Thomson and Martinet (1986: 35) suggested that the order should be: size - general description like personality, emotion - age shape - color - material - origin - purpose. The examples are: a long sharp knife, a small round table, blue velvet curtains, a kindly black doctor. Several variations are possible, but a fairly usual order is needed in this case.

From the above explanation, the researcher would like to analyze the students' ability in using descriptive adjective in English sentences. Some mistakes could probably happen as the students still get confusion how to put the descriptive adjectives correctly. By performing this research, hopefully this research could help the students' difficulty in using descriptive adjective in English sentences.

\section{The Formulation of the Problem}

The problems of this study will be formulated as follows:

1. Are the students able to use descriptive adjective in sentences?

2. What are the students' difficulties in using descriptive adjective in sentences?

\section{The Objective of the Study}

The objectives of the study will be focused:

1. to find out the students' ability to use descriptive adjective in sentences, and 
2. to describe the students 'difficulties in using descriptive adjective in sentences.

\section{Definition of Ability}

The word 'ability' is derived from the word 'able', which has the similar meaning with 'can'. Hornby (1995: 20) said that Ability is the skill or competence of doing something. The meaning of this word is the situation being able. It is also as potential capacity or power to doing something physical or mental. Worldbook (2005: 47) explains "Ability means the power to do or act, skill, power to do some special thing; natural gift; talent". It is also another word for capability. Ability is the quality or state or being able especially in physical, mental, leg as power to perform.

So, based on their explanation, the researcher take her own summary that ability is skill to take a certain attitude to watch something with understanding to create new something to prove how far the students success in learning process in their level class. Hasan (1995: 64) says "In human basic potential there are three factors that can make they students' ability more increasing". They are:

a. The original ability (natural ability)

It is the original ability is a set of basic ability and it is called fitrah ability (basic ability that can be developed automatically). The basic ability will develop by integral that can move all of its aspects. So that, all of the aspects can influence each other to get special aims mechanically. Some factors can improve original ability are: talent, instinct, hereditary, intuition, and human character.

b. Thinking ability

In structure of human body there is called a brain extension, which is used to think something. Thinking as a sign of soul that can make correlation between incidents that has done. There are three processes in thinking ability to form inner ability, namely: form of sense, form of thinking, and form of decision.

c. Ability derived from willingness

Willingness as a sign of soul, describes one active of feeling as an effort of individual soul. Willingness is an effort to someone to raise something in us. Ability derived from willingness can be seen from signs as follows: drives, wishing, interest, inclination, and willingness.

\section{Descriptive Adjective}

In grammar, an adjective is a word whose main syntactic role is to modify a noun or pronoun, giving more information about the noun or pronoun's definition. Some examples can be seen in the box to the right. Collectively, adjectives form one of the traditional English eight parts of speech, though linguists today distinguish adjectives from words such as determiners that also used to be considered adjectives.

Wren and Martin (1993: 19) described that adjective as a word used with a noun to describe or point out, the person, animal, place, or thing which the noun names, or to tell the number or quantity. Meanwhile, Sharpe (2000: 163) stated that Adjectives and adjective phrases describe nouns. They may be used to describe quantity (number or amount), sufficiency (number or amount needed), consecutive order (order in a sequence), quality (appearance) and emphasis (importance of force). Descriptive adjectives are the largest class of the four types of adjectives, the others being adjectives of quantity, demonstrative adjectives, and pronominal adjectives. 
In other words, descriptive adjectives are words that function to describe nouns. Specifically, adjectives describe the action, state, or quality that nouns refer to. Most adjectives and adjective phrases have only one form in English. They do not change to agree with the nouns they describe.

\section{Kinds of Descriptive Adjective}

Ting (2008: 2) describes that there are three kinds of descriptive adjectives. The three kinds of descriptive adjectives are as follows:

(1) Simple Adjectives, that is expressing quality; such as safe, happy, deep, fair, rash, beautiful, remotest, terrible, etc.

(2) Compound Adjectives, made up of various words thrown together to make descriptive epithets. Examples are Heaven-derived power, this life-giving book, his spirit wrapt and wonder-struck, ice-cold water, half-dead traveler, unlooked-for burden, next-door neighbor, ivory-handled pistols, the coldshudder-inspiring Woman in White.

(3) Proper Adjectives, derived from proper nouns; such as, an old English manuscript, the Christian pearl of charity, the well-curb had a Chinese roof, the Roman writer Palladius.

\section{Simple Adjectives}

Simple adjectives, as their name suggests, are the most basic type of descriptive adjectives. They function to express quality. Aspects such as feelings, time, sound, quantity, taste, appearance, size, age, color, shape, and material are expressed through simple adjectives. The following list highlights some common examples:

swift ancient modern

tan beige chestnut

$\begin{array}{ll}\text { sticky } & \text { fuzzy giant } \\ \text { careful } & \text { cheap expensive } \\ \text { bumpy } & \text { cool few } \\ \text { bitter } & \text { sweet } \\ \text { alert } & \text { attractive } \\ \text { teeny } & \text { massive } \\ \text { good } & \text { bad } \\ \text { rainy } & \text { solid }\end{array}$

\section{Compound Adjectives}

Compound adjectives are created when two words are combined to create a descriptive adjective. The two words are typically connected with a hyphen. The following list provides some common examples of compound adjectives:

self-centered ice-cold next-door

long-legged four-sided three-headed

candy-stripped left-handed freckle-faced

life-giving bow-legged

pigeon-toed high-heeled

short-tempered heavy-handed

\section{Proper Adjectives}

The following list provides a number of these descriptive adjectives that are derived from proper nouns. Nations, regions, and religions are common qualities described by proper adjectives. Because they are derived from proper nouns, proper adjectives are always capitalized. For examples:

$\begin{array}{lll}\text { Italian } & \text { French } & \text { English } \\ \text { Mexican } & \text { Canadian } & \text { Roman } \\ \text { German } & \text { American } & \text { Buddhist } \\ \text { Indonesian } & \text { Mayan } & \\ \text { Christian } & \text { Chinese } & \\ \text { Hindu } & \text { Spanish } & \end{array}$

\section{Definition of Sentence}

A sentence is a string of words, which makes complete sentence. It consists of at least 
one subject and one predicate. However, may mean statement by a judge, or punishment. Hornby (1983: 776) says "sentences mean the grammatical unit, consisting of phrase, and / or clause, used to express a statement, question, command". Frank (1972: 220) said that a sentence is an important part of the text and to shape the basic of unit written English language communication. Every sentence in English has a subject (what is being talked about) and a predicate (what describes the subject). In a sentence, therefore, there are words (part of speech) that are ordered in such a way as to produce acceptable meanings.

Sharpe (2000:270) explained that there are different views as to the nature of a sentence, in traditional grammar; a sentence is a viewed from the meaning. As a result, there are many definitions of sentence. According to the traditional grammar (perspective grammar) a sentence is a group of word expressing a complete thought. This definition obviously creates more confusion than a clear understanding of the nature of a sentence. The term "a complete thought" can be anything for a simple idea to a complex one. Thus, this definition is defined and revised.

Wren and Martin (1993: 67) say "Sentence is a group of words like this, which makes complete sense". The Wren and Martin's opinion means that the sentences may be written or spoken. Here the sentence is a group of words that makes complete sense, especially in the written form. Based the quotation above the writer concludes that a sentence means a grammatical unit that consists of phrase or clause and has a special sense.

\section{Kinds of Sentences}

\section{Simple Sentences}

A simple sentence means a sentence that consists of only one clause, which is the main clause. Hornby (1983: 799) says "simple sentence is one without subordinate clause". And Wren and Martin (1993: 128) say "simple sentence is one which has only one subject and one predicate. It means that simple sentences consists only one subject, one predicate, one subject or one complement". For examples:

(1) He works

$$
S \quad P
$$

(2). He writer a letter

$$
\mathrm{S} \quad \mathrm{P} \quad \mathrm{O}
$$

(3) We study English everyday

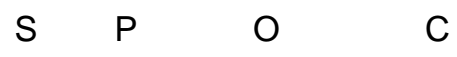

The examples above show that simple sentences many consists of only one subject and one predicate, one subject one predicate and object, one subject one predicate one object and complement.

Simple sentences, as in (1) is determined in the definition, and express only one special sense. It may be varied in tenses, according to the sense intended. The variation of tenses will vary form of the predicate. For examples: They come here everyday (Simple present, plural), He comes here everyday (Simple present, singular), $\mathrm{He}$ came here everyday (Simple past), and He will come here next week (Simple future). The examples above show that the predicate of the simple sentences depend on the kind of tenses, and the number of the subject.

\section{Compound Sentences}

Larson (1986:88) explained that a compound sentence is a sentence that consist of 
one subject and two predicate, or a sentence that consists of two or more independent clauses that express closely ideas and each and stand alone as a simple sentence. The quotation above those compound sentences consists of two or more subject and predicate, since a clause has one subject and one predicate. For example:

(4) The horse reared and the rider was thrown.

$$
\begin{array}{llll}
\mathrm{S} 1 & \mathrm{P} 1 & \mathrm{~S} 2 & \mathrm{P} 2
\end{array}
$$

The example above show that compound sentences may be consists of two or more subject and predicates, however in this study the writer discuss only which consists of two subjects and two predicates (double sentences).

\section{Location and Time of the Research}

This research was conducted at MAN Tanjung Morawa at Jalan Limau Manis Pasar 15 Desa Medan Sinembak, Tanjung Morawa. The reason for choosing the school is that this school was accessible in terms of time and fund.

\section{Population}

Arikunto (2002: 108) states "Population is the whole number of the objects that obtained or available on the field". In other words, a population is a group of individuals persons, objects, or items from which samples are taken for measurement for example a population of presidents or professors, books or students.

This research took the second year $(\mathrm{XI})$ 2008/2009 of MAN Tanjung Morawa at Jalan Limau Manis Pasar 15 Desa Medan Sinembak, Tanjung Morawa as the population. There are three classes for XI students that consist of 102 students in which class XI IPA1 $=30$ students, $X I$ IPA2 $=36$ students, and XI IPS $=36$ students.

\section{Sample}

Arikunto (2002:109) says that sample is the certain number of the whole population of objects obtained or available on the field. In other words, A sample is a finite part of a statistical population whose properties are studied to gain information about the whole. When dealing with people, it can be defined as a set of respondents (people) selected from a larger population for the purpose of a survey.

This research took $20 \%$ from the population. Arikunto says that if $10-15 \%$ and 20 $-25 \%$ or more as sample when the population is more than 100 is enough unless we take them all as described in the following table:

Table 1

Population of the Students

\begin{tabular}{|l|l|c|}
\hline No & Class & Population \\
\hline & XI IPA1 & 30 \\
\hline 2 & XI IPA2 & 36 \\
\hline 3 & XI IPS & 36 \\
\hline \multicolumn{2}{|c|}{ Total } & 102 \\
\hline
\end{tabular}

Table 2

Sample of the Research

\begin{tabular}{|c|c|c|c|}
\hline No & Class & $\mathbf{2 0} \%$ & Sample \\
\hline 1 & XI IPA1 & 6 & 6 \\
\hline 2 & XI IPA2 & 7.2 & 7 \\
\hline 3 & XI IPS & 7.2 & 7 \\
\hline \multicolumn{2}{|l|}{ Total } & 20.4 & 20 \\
\hline
\end{tabular}

\section{Research Design}

Arikunto (2002:2) explains that research is an action conducted by someone who works on what is he is doing without changing the system of the performance. This research used a descriptive 
quantitative method. It means that a scientific approach that most of it used numbers for presenting the data, and the result of the research. This method describes the students' ability to use the descriptive adjective in English sentences.

To obtain the sample randomly, this research took the sample based on the names of the students' attendance list. The odd numbers were taken from number 1,3,5,7,9, and so on.

\section{Technique for collecting the data}

For collecting the data, some steps was performed as follows:

1. This research was developed a test of completion test in order to see the results of the students' ability to use descriptive adjective in English simple sentences,

2. The correct answer was scored 5 and the wrong answer did not affect the score,

3. The set of the test was administrate to the students, which consisted of 20 (twenty) completion test-items

\section{Technique of Data Analysis}

The data were analyzed by using a descriptive quantitative technique. In this technique, the data were analyzed in term of quantitative analysis. The steps of the technique were performed as follows:

1. Giving the test related to the descriptive adjective in English simple sentences,

2. Collecting the students' answer sheet,

3. Finding out the correct and incorrect answers and concluding in the students' result,

4. Calculating the percentage of the students' result in constructing of descriptive adjective in simple sentence as suggested by Sudijono (1999:76)

$$
P=\frac{F}{N} x 100 \%
$$

Where: $\mathrm{P}=$ the percentage of the students' ability and inability

$$
F=\text { the number of the students' ability and }
$$
inability

$$
\mathrm{N}=\text { the number of the sample test }
$$

5. Calculating the students' results in English grammar by giving Sudijono's scores:

\begin{tabular}{|c|c|}
\hline Quantitative Ability & Qualitative Ability \\
\hline $80-100$ & Very good \\
\hline $60-79$ & Good \\
\hline $50-59$ & Poor \\
\hline$\leq 40$ & Very poor \\
\hline
\end{tabular}

6. Finding out the students' difficulties in using descriptive adjective in English simple sentences,

7. Finding out the validity of the test by using the formula of Arikunto (1993: 230) who recommended that the value of validity is as follows:

$$
r_{x y}=\frac{N x \Sigma_{x y}-\left(\Sigma_{x}\right)\left(\Sigma_{y}\right)}{\sqrt{\left(N \times \Sigma x^{2}-(\Sigma x)^{2}\right) \times\left(N \times \Sigma y^{2}-(\Sigma y)^{2}\right)}}
$$

\section{DATA ANALYSIS}

After the test was distributed and the researcher obtained the data then data were analyzed. They were analyzed by using the percentage of each student's score and their qualitative ability as can be seen in the following table. 
Table 4

The Percentage of the Students' Score in using Descriptive Adjective

\begin{tabular}{|c|c|c|c|c|}
\hline No & $\begin{array}{c}\text { Students' } \\
\text { Initial }\end{array}$ & $\mathbf{N}$ & $\mathbf{K}$ & $\mathbf{Q}$ \\
\hline 1 & $\mathrm{JU}$ & 15 & 20 & $75 \%$ \\
\hline 2 & $\mathrm{MM}$ & 20 & 20 & $100 \%$ \\
\hline 3 & $\mathrm{JH}$ & 11 & 20 & $55 \%$ \\
\hline 4 & $\mathrm{ES}$ & 14 & 20 & $70 \%$ \\
\hline 5 & $\mathrm{FK}$ & 11 & 20 & $55 \%$ \\
\hline 6 & $\mathrm{SM}$ & 10 & 20 & $50 \%$ \\
\hline 7 & $\mathrm{AR}$ & 6 & 20 & $30 \%$ \\
\hline 8 & $\mathrm{HZ}$ & 9 & 20 & $45 \%$ \\
\hline 9 & $\mathrm{MA}$ & 11 & 20 & $55 \%$ \\
\hline 10 & $\mathrm{NA}$ & 13 & 20 & $65 \%$ \\
\hline 11 & $\mathrm{NH}$ & 15 & 20 & $75 \%$ \\
\hline 12 & $\mathrm{SH}$ & 10 & 20 & $50 \%$ \\
\hline 13 & $\mathrm{NR}$ & 14 & 20 & $70 \%$ \\
\hline 14 & $\mathrm{WP}$ & 10 & 20 & $50 \%$ \\
\hline 15 & $\mathrm{NY}$ & 12 & 20 & $60 \%$ \\
\hline 16 & $\mathrm{DS}$ & 13 & 20 & $65 \%$ \\
\hline 17 & $\mathrm{RN}$ & 13 & 20 & $65 \%$ \\
\hline 18 & $\mathrm{AH}$ & 11 & 20 & $55 \%$ \\
\hline 19 & $\mathrm{AS}$ & 9 & 20 & $45 \%$ \\
\hline 20 & $\mathrm{AN}$ & 1 & 20 & $5 \%$ \\
\hline
\end{tabular}

Note:

$\mathrm{K}=$ the number of items

$\mathrm{N}=$ the number of correct items

$Q=$ the percentage of the correct items

The formula was used as follows

$$
Q=\frac{K}{N} \times 100 \%
$$

\section{The findings}

After analyzing all the data, the some findings can be presented as follows:

1. From 20 students, there were 9 students or $45 \%$ were categorized as able,

2. From 20 students, there were 11 students or $55 \%$ were categorized as unable,

3 . The result of validity of the test is 0.67 . It means that the test is "high to validity",
4. The value of standard reliability above, then the result of reliability of the test is 0.80 . It means that the test is "very good".

5. The test item number 7 was the most difficult one in which only 2 students were able in using descriptive adjective correctly. The test item number 7 related to the Compound Adjective.

\section{Conclusion}

From the data and findings of the research, the researcher concludes as follows:

1. The findings show that 9 students or $45 \%$ from the whole sample were able in using descriptive adjective. Meanwhile there were 11 students or $55 \%$ from the whole sample were unable in using descriptive adjective. In other words, the students of MAN Tanjung Morawa especially the second year (XI) 2008/2009 in Jalan Manis Pasar 15 Desa Medan Sinembak, Tanjung Morawa were unable to use using descriptive adjective in sentences.

2. The test item number 7 was the most difficult one in which only 2 students were able in using descriptive adjective correctly. The test item number 7 related to the Compound Adjective. In other words, the students of MAN Tanjung Morawa especially the second year (XI) 2008/2009 in Jalan Manis Pasar 15 Desa Medan Sinembak, Tanjung Morawa had a problem in compound adjective.

\section{REFERENCES}

Arikunto. S. 2002. Prosedur Penelitian. Jakarta: Rineka Cipta Press.

Arnold, Michael. 1995. The Language Style. London: Longman. 
Djuhari, Otong Setiawan. 2003. Bagaimana Mengungkapkannya Dalam Bahasa Inggris, Bandung: Yrama Widya.

Frank, Michael. 1972. English Writing Sentences. Cambridge: University Press.

Hassan, Chalijah. 1995. Dimensi-dimensi Psikologi Pendidikan. Al-lkhlas: Surabaya.

Hornby, A. S. 1995. Guide to Pattern and Usage in English. Hongkong: Sing Cheong pritingco.

Larson, C.U. 1986. Persuasion: Reception and Responsibility. Belmont California: Wadsworth.

Patton, M.Q.1990. Qualitative evaluation and research methods. New Delhi : SAGE Publications \& Newbury Park London.

Pickthall, Marmadake. 1990. The Meaning of the Glorious Qur'an. Karachi: Raj, Company Limited.

Rachmadie, Sabrony. 1985. Vocabulary. Jakarta: Depdikbud Universitas Terbuka.

Sharpe, Pamela. 2000. Barron's How to Prepare For the TOEFL Test. Jakarta: Binarupa Aksara.

Sudijono, Anas. 1999. Pengantar Evaluasi Pendidikan. Jakarta: Raja Grafindo Persada.

Thomson, A.J and A.V Martinet. 1986. A Practical English Grammar. Oxford: Oxford University Press.

Tim Penyusun. 1999. Pedoman penulisan skripsi dan Ujian skripsi, Medan: FKIP UMSU (unpublished).

Ting, Teresa. 2008. Classroom Handout: The Order of Descriptive Adjectives. Calabria, Italy: University of Calabria.

World Book Encyclopedia Delux. 2005. World Book. America: Delux Production.
Wren, P.C Martin. 1993. High School English Grammars and Composition. New Delhi: Chan S Company Ltd. 